\title{
Physiology of salinity tolerance in tilapia : an update of basic and applied aspects
}

\author{
Patrick Prunct ${ }^{(1)}$ and Michel Bornancin ${ }^{(2)}$ \\ (1) IVRA, Laboratoire de Physiologie des Poissons, \\ Campus de Beaulieu, 35042 Rennes cedex, France. \\ (2) Université de Nice, Laboratoire de Physiologie cellulaire et comparée, \\ Faculte des Sciences et des Techniques, parc V'alrose, oconzt Nïe cedex, France.
}

Received Scptember 9, 1988 ; accepted January 9, 1989.

Prunet P., M. Bornancin. Aquat. Liting Resour., 1989, 2, 91-97.

Abstract

Tilapia species are generally characterized by a large tolerance to salinity; however, such capacity to adapt to brackish or seawater may be modulated by environmental factors. The major osmoregulatory mechanisms involved in salinity adaptation are presented. Most of the available data concern the role of gills in salt or water exchange. The importance of different factors (environmental or endogenous) in such adaptation is also discussed. The second part presents a survey of the endocrine control of osmoregulation in tilapia. Both fast-acting (e.g. glucagon, urotensins, catecholamines) and long-acting (e. g. prolactin, cortisol) hormones have been studied. In conclusion, several areas of osmoregulatory physiology potentially interesting for aquaculture are discussed.

Keywords : Salinity, tilapia, osmoregulation, hormones.

Physiologie de la tolérance à la salinité chez tilapia: aspects fondamentaux et appliqués.

Résume

Les tilapias sont caractérisés par une large tolérance à la salinité, cependant cette capacité d'adaptation à l'eau saumâtre ou l'eau de mer peut être modulée par des facteurs environnementaux. Les principaux mécanismes osmorégulateurs impliqués dans cette adaptation sont présentés. La plupart des résultats concernent le rôle des branchies dans les échanges d'eau et de sel. L'importance de différents facteurs (environnementaux ou endogènes) est aussi abordée. La seconde partie de cette synthèse est consacrće à l'ćtude du contrôle endocrinien de l'osmorégulation chez le tilapia. L'étude des hormones à action rapide (ex. glucagon, urotensines, catecholamines) et à action lente (ex. prolactine, cortisol) a été envisagée. En conclusion, plusieurs domaines de la physiologie de l'osmorégulation potentiellement intéressants pour l'aquaculture ont été suggérés.

Mots-clés : Salinité, tilapia, osmorégulation, hormones.

\section{INTRODUCTION}

Fish of the genera Tilapia and Sarotherodon are characterized by a general tolerance to a wide range of environmental conditions. Their tropical origin is clearly reflected in their preferred temperature: these fishes do not tolerate temperatures below $12^{\circ} \mathrm{C}$ but are remarkably tolerant to high temperatures, up to $42^{\circ} \mathrm{C}$ (Chervinski, 1982). Moreover, several tilapia species possess a marked euryhalinity and numerous reports have described these species in estuarine or coastal areas of $\Lambda$ frica (see review by Stickney, 1986). 
This tolerance is not limited to saline waters but also includes environments with poor water quality. Among other factors, good growth and prolific breeding have certainly favoured the large development of tilapia aquaculture observed in recent years.

Competition with agriculture has increased pressure to develop tilapia aquaculture in marginal areas such as brackish water or seawater (Payne, 1983). However, salinity tolerance alone does not necessarily mean suitability for optimal production and tilapia species such as $O$. niloticus which were chosen for their aquacultural potentiality (mainly high growth rate) are not particularly euryhaline. Conversely, O. mossambicus which is among the most euryhaline species, has been rejected due to its relatively slow growth. This has led to the development of hybrid species, such as the red tilapia (produced by crossing female $O$. mossambicus $\times O$. hornorum with male $O$. niloticus) as a good candidate for brackish water or seawater aquaculture (Liao and Chang, 1984).

Poor gowth and mortality among different tilapia species cultured in brackish water have been reported recently (Doudet, 1986; Morissens, 1987). This appears to be in contradiction with the classical picture of salinity tolerance of these tilapia species. However, most of these studies on euryhalinity were undertaken in the laboratory and sometimes over a short period of time. In natural brackish water, fish have to face fluctuations during several months of environmental conditions such as salinity, watcr quality or temperature, which may make salinity adapta. tion more difficult. Evaluation of the physiological importance of such parameters is still lacking.

In an attempt to acquire a clearer picture of the adaptation of tilapia to salinity, different aspects of the physiology of osmoregulation will be presented in this review: the first part will deal with major physiological mechanisms involved in salinity adaptation and the importance of different modulatory factors for such adaptation. The second part will focus on the current knowledge of endocrine control of osmoregulation in tilapia.

\section{OSMIOREGULATION}

In terms of thermodynamics, fish, like other aquatic organisms, represent an open system in dynamic equilibrium with aquatic surroundings. Steady state is reached as a result of exchanges between the fish and its environment: on the one hand, by passive fluxes, such as thermal exchanges occurring through the whole body surface in contact with water; on the other hand, by regulated fluxes taking place across specialized membranes such as gills, digestive tract or renal tubules.

The branchial cpithelium which is in intimate contact with the external environment is responsible for many complex functions in fish, including respiration, excretion, acid-base balance, ionic and osmotic regulations. Although the gill epithelium area is four times greater that of the body, providing oxygen from a low concentration of oxygen in the water requires a continuous flow of water through the gills. This means that branchial cells are constantly exposed to natural and artificial chemicals. Thus, respiratory or osmoregulatory branchial exchanges mechanisms, vital for the organism, can be modified by changes in the external environment.

If the energy costs of respiration and osmoregulation are low (e. g., when ecophysiological equilibrium with the external medium is ideal), then the proportion of metabolic energy which is available for growth is greater. For instance, temperature and salinity of water are important characteristics which can modify survival, growth and reproduction of fishes and limit the distribution of the species. Tilapia salinity tolerance has often been tested. However, little is known about the osmoregulatory mechanisms of these fish. So we shall first review the results published on branchial salt exchanges and the possible role of $\mathrm{Na}^{+}$, $\mathrm{K}^{+}$-ATPase in these exchanges and then we shall comment on the salt water tolerance of tilapia. This point has been recently reviewed (Chervinski, 1982; Stichney, 1986).

\section{Salt exchanges: branchial role}

Previous investigations by Potts et al. (1967) have shown that drinking rate, rate of sodium exchange and total body sodium increased when Oreochromis mossambicus was adapted to seawater; the drinking rate accounted for only one quarter of the total sodium influx in seawater, whereas the remaining three quarters resulted from branchial or skin exchanges. It is generally admitted that the branchial cpithelium is the major salt transport site in fishes both for salt uptake in fresh water (Evans, 1980; Payan et al., 1984) and salt excretion in seawater (Maetz and Bornancin, 1976). In the same species (O. mossambicus) Dharmamba et al. (1975) studicd scawater adaptation. Fish adapted to fresh water, one-third scawater and full seawater were compared in regard to their branchial $\mathrm{Na}^{+}$and $\mathrm{Cl}^{-}$influxes and effluxes. Results are presented in table 1. Plasma $\mathrm{Na}^{+}$and $\mathrm{Cl}^{-}$remain practically conslant in all three media, showing the good adaptability of the fish. However, upon adaptation from fresh water to $1 / 3$ seawater or full seawater, the rate of effluxes increased 15 and 206 times respectively. Similarly, a large increase in $\mathrm{Na}^{+}$turnover rate was observed after adaptation to one-third scawater and full scawater. These last values were recently confirmed in Tilapia grahami by Eddy and Maloiy (1984).

Some parallelism was observed between $\mathrm{Na}^{+}$branchial fluxes and $\mathrm{Na}^{+}, \mathrm{K}^{+}-A$ TPase activity in gill tissues (see table 1 and Dharmamba et al., 1975). The significant increase in gill $\Lambda$ TPasc activity in relation to external salinity is similar to those observed in various other teleosts (De Renzis and Bornancin, 
Table 1. - Ionic changes with seawater adaptation of Oreochromis mossambicus (from Dharmamba et al. 1975).

\begin{tabular}{|c|c|c|c|c|}
\hline & & \multicolumn{3}{|c|}{ Adaptation medium } \\
\hline & & FW & $1 / 3 \mathrm{SW}$ & SW \\
\hline Masma values (meq. 7 ) & $\begin{array}{l}\mathrm{Na}^{+} \\
\mathrm{Cl}^{-}\end{array}$ & $\begin{array}{c}158.5 \pm 2.2 \\
(n=12) \\
139.0 \pm 1.0 \\
(n=12)\end{array}$ & $\begin{array}{c}163.2 \pm 2.5 \\
(n=9) \\
149.5 \pm 2.2 \\
(n=9)\end{array}$ & $\begin{array}{c}163.8 \pm 2.0 \\
(n=1) \\
146.2 \pm 1.7 \\
(n=11)\end{array}$ \\
\hline Influx ( $\mathrm{eq} \mathrm{h} / 100 \mathrm{~g}$ ) & $\begin{array}{l}\mathrm{Na}^{+} \\
\mathrm{Cl}^{-}\end{array}$ & $\begin{array}{c}13.6 \pm 2.5 \\
(n=8) \\
11.4 \pm 2.9 \\
(n=6)\end{array}$ & $\begin{array}{c}116 \pm 29 \\
(n=6)\end{array}$ & $\begin{array}{c}746 \pm 79 \\
(n=6)\end{array}$ \\
\hline Erחux ( $\mu \mathrm{cq}, h / 100 \mathrm{~g})$ & $\begin{array}{l}\mathrm{Na}^{+} \\
\mathrm{Cl}^{-}\end{array}$ & $\begin{array}{c}8.4 \pm 1.3 \\
(n=8) \\
8.0 \pm 2.4 \\
(n=8)\end{array}$ & $\begin{array}{c}125 \pm 56 \\
(n=5)\end{array}$ & $\begin{array}{c}1651 \pm 171 \\
(n=8) \\
1538 \pm 339 \\
(n=4)\end{array}$ \\
\hline $\begin{array}{l}\mathrm{Na}^{+} \\
\text {Tumover rates, } \mathrm{h} \\
\text { Gill microsomal } \\
\mathrm{Na}^{+} \mathrm{K}^{+} \text {ATPase activity } \\
\left(\mu \mathrm{mol} \mathrm{Pi}^{\prime} \mathrm{mg} \text { prot } / \mathrm{h}\right)\end{array}$ & & $\begin{array}{c}2.4 \% \\
1.5 \pm 0.1 \\
(n=12)\end{array}$ & $\begin{array}{c}3.5 \% \\
2.8 \pm 0.7 \\
(n=9)\end{array}$ & $\begin{array}{c}40^{\circ} ; \\
3.5 \pm 0.8 \\
(n=11)\end{array}$ \\
\hline
\end{tabular}

1984). Similar observations were made by Valverde et al. (1982) on Tilapia rendalli and by Dangé (1986a) on Oreochromis mossambicus.

Uptake of other ions have also been ascribed to the gills. Flik et al. (1985) showed that $\mathrm{Ca}^{2+}$ entry was mainly extra-intestinal and presumably through the branchial epithelium. These results obtained on freshwater-adapted Oreochromis mossambicus confirm the important role of ambient water as a source of $\mathrm{Ca}^{++}$.

Recently it has been shown in trout by Avella et al. (1987) that the external medium (so-called "fresh water") encompasses several situations which are quite different in term of $\mathrm{pH}$ and $\mathrm{Na}^{+}, \mathrm{Cl}^{-}$or $\mathrm{Ca}^{2+}$ concentrations. When fishes are exposed long enough to fresh water with different ionic concentrations, morphological modifications of the gill tissues occur and can be related to different physiological performances of the branchial epithelium. In freshwater trout, sodium uptake was related to the abundance of "mitochondria-rich cells" on the secondary lamellac (Avella et al,, 1987). These cells (chloride cells), large, granular and mitochondrion-rich, were first observed in the gills of seawater adapted eels (Keys and Villmer, 1932) and have been implicated in salt secretion in scawater (Mactz and Bornancin, 1976; Foskett and Scheffey, 1982).

In scawatcr-adapted fish, chloride cells are located on the filaments (primary lamellae) of the gills, and the number of chloride cells increases following salt water transfer (Mactz and Bornancin, 1975). In the case of Oreochromis mossambicus, chloride cells also occur in the opercular membrane, and thus allow physiological studies on chloride cell development during salt water adaptation (Foskett et al., 1981). These authors showed that opercular membranes from seawater-adapted tilapia contain typical large chloride cells which are absent from freshwater tissues, although rudimentary chloride cells are present.
Following scawater transfer, the number of chloride cells increased during the first 3 days, and subsequently hypertrophy of these cells occurred. The most interesting conclusion which emerges from this work is the high corrclation betwecn increasing number and differentiation of chloride cells and salt extrusion.

Other parameters should be taken into consideration during the acclimation process of tilapia to salt water. Assem and Hanke (1983) for cxample, have demonstrated the participation of amino acids such as taurine and glycine in the osmotic adjustment of muscle cells.

\section{Salinity tolerance}

The ability of tilapia to develop the above physiological mechanisms allows them to survive after transfer from fresh water to brackish water or seawater. Although tilapia species are broadly curyhaline and can tolerate a wide range of salinity, such ability to withstand salinity varies according to the species. Surveys of the existing literature on the salinity tolerance of the different tilapia species have already been published (see reviews Philippart and Ruwct, 1982; Chervinski, 1982; Payne, 1984; Stickncy, 1986), and it is not our purpose to duplicate such reviews.

Adaptability to salinity can be modulated by several factors, i.e., cnvironmental or endogenous. In a recent study on the ontogeny of salinity tolerance, Watanabe et al. (1985a) indicated a close relationship with size, larger fish adapting easier to higher salinities. In another study, the same authors also showed that salinity tolerance could be increased by early exposure to salinity (during spawning or hatching): they observed the best salinity tolerance after the earliest and highest salinity exposure (Watanabe et al., 1985b). Such results could certainly be of practical importance and more studies should be devoted to the physiology of such adaptability during early deve- 
lopment and to the ontogeny of this phenomenon. Fceding may also modily scawater adaptability, and a high salt diet was shown to improve survival rate of several Oreochromis species transferred into a hyperosmotic environment (Al-Amoundi, 1987). Finally, environmental factors, such as temperature, dissolved oxygen and ammonia, also modulate salinity acclimation (Beanish, 1970; Farghaly et al., 1973; Whitfield and Blaber, 1976), but the impact of such factors on hypo-osmoregulatory capacity still needs to be clarified. Thus, although several biological investigations have been devoted to salinity tolerance of tilapia, still more physiological studies are needed, and it would be especially interesting to evaluate the importance of different freshwater pre-acclimations on the capacity to adapt to salt water.

\section{HORMIONAL CONTROL OF OSMOREGULATION}

As in other teleost species, studies on hormonal control of tilapia osmoregulation have involved both rapidly-acting hormones (catecholamines, somatostatin, glucagon, VIP, urotensins) and slowly acting hormones (prolactin, cortisol, thyroid hormones).

Prolactin (PRL) was among the hormones first studied in Oreochromis mossambicus: Handin et al. (1964) first showed the inability of hypophysectomized tilapia to survive in fresh water, and Dharmamba et al. (1967) demonstrated that PRL treatment promoted survival of these hypophysectomized fish. Further studies confirmed PRL involvement: treatment of these hypophysectomized fish kept in fresh water with PRL restored the sodium balance by reducing the sodium efflux (Dharmamba and Mactz, 1972). Moreover, injections of PRL in seawateradapted tilapia induced increase in plasma sodium level and osmolarity (Dharmamba et al., 1973). This effect of PRL was demonstrated mainly to inhibit both total $\mathrm{Na}^{+}$influx and cfllux (Dharmamba and Maetz, 1976) which resulted in a loss of intracellular water and then an increase in intracellular $\mathrm{K}^{+}$ (Loretz, 1979). The osmoregulatory property of PRL is the basis for the development of an in tivo bioassay based on plasma $\mathrm{Na}^{+}$increase after PR L injections in scawatcr-adapted Oreochromis mossambicus (Clarke, 1973).

Electrophysiological and radiotracer technics were applied to the isolated opercular membrane (containing numerous chloride cells) from Oreochromis mossambicus, permitting the study of hormonal control of cellular mechanism involved in adaptation to fresh water or to seawater. In seawater-adapted tilapia, PRL appeared to inhibit chloride secretion by the opercular membrane, probably through a dedifferentiation effect on the chloride cell population (Foskett et al., 1982a). Recently, studies in fresh water-adapted tilapia of whole-animal transepithclium potential (TEP) have indicated a significant decrease of this parameter after hypophysectomy (Young et al., 1988). Injections of these fish with tilapia $P R L$ restored both TEP and plasma $\mathrm{Na}^{+}$and $\mathrm{Cl}^{-}$levels measured in sham-operated fish (Young et al., 1988). Moreover, in the same study, tilapia PR L appeared to be ineffective on gill $\mathrm{Na}^{+}, \mathrm{K}^{+}-\mathrm{ATPase}$ activity. These results are consistent with an inhibitory effect of PRL on epithelial ion permeability in fresh water, as suggested in other species (Clarke and Bern, 1980). Moreover, PRL has also been shown to decrease water permeability in isolated gills of tilapia (Wendelaar Bonga and Van der Meij, 1981).

Purification of tilapia PRL (Farmer et al., 1976) allowed the development of an homologous radioimmunoassay which was used to measure plasma and pituitary PRL levels. Transfer from scawater to fresh water induced a 7-12 increase in plasma PRL levels (Nicoll et al., 1981). Moreover pituitary PRL content, estimated by means of histological studies or radioimmunoassay, decreases in scawater compared to freshwater (Dharmamba and Nishioka, 1968; Nicoll et al., 1981). These data are consistent with an important role of PRL in freshwater osmoregulation. Moreover, low but consistent levels of PRL in scawateradapted fish support a possible role of this hormone in scawater osmoregulation, as suggested by Foskett et al. (1983). Recently, a second PRL molecule has been characterized from the culture medium of tilapia pituitary (Specker et al., 1985). The complete sequences of the two tilapia PRL were determined (Yamaguchi et al., 1988) and one of them appeared to be 11 amino acids longer than the smaller one. In spite of these biochemical differences, both PRL hormones present similar osmorcgulatory activity in freshwater-adapted tilapia (Specker et al., 1985; Young et al., 1988). Further studies are needed to determine whether each PRL has specific physiological functions.

The major corticosteroid in fish, cortisol, has long been implicated in seawater adaptation of teleosts (Hirano and Mayer-Gostan, 1978); its involvement in tilapia osmoregulation has not benefitted from many investigations. Assem and Hanke (1981) have measured changes in plasma cortisol levels during transfer experiments. They observed a temporary increase in cortisol level after each transfer (fresh water to seawater and the converse) and suggested that cortisol may be necessary for metabolic changes involved in cell volume regulation. Moreover, cortisol reduce the intracellular shrinkage obscrved after seawater transfer (Assem and Hanke, 1981). A more direct involvement of cortisol in tilapia osmoregulation has becn shown by Dange ( $1986 b)$ who obscrved an increase of gill $\mathrm{Na}^{+}, \mathrm{K}^{+}-\Lambda$ TPase activity after cortisol treatment. Moreover, Foskett et al. (1981), using isolated opercular membrane, showed an increase in chloride cell density after cortisol treatment, but without activation of chloride sccretion. Interestingly, cortisol treatment associated with hypophysectomy still did not stimulate chloride sccretion (Foskett et al., 1983), leading the authors to suggest the involve- 
ment of the other factors, probably environmental, to initiate salt secretion by chloride cells. Nevertheless, this work clearly shows the involvement of cortisol in the stimulation of chloride cell differentiation which is, in turn, inhibited by PRL in seawateradapted tilapia.

Control of tilapia osmoregulation by fast-acting hormones has been examined only using in ritro approaches (isolated intestin or opercular membrane). Epinephrinc, somatostatin and urotensin II inhibit chloride secretory flux from the opercular membrane, whercas glucagon and VIP stimulates such secretion (Foskett et al., 1982 b; 1983). This effect is probably obtained through modulation of intracellular $\Lambda M P c$ in chloride cells. The osmoregulatory role of VIP, urotensin I and II have also been shown through their effects on water exchange and ion absorption in the anterior intestine of tilapia adapted to cither fresh water or scawater (Mainoya and Bern, 1982; 1984). Although no in tivo data are available, these factors may be important regulators of osmoregulation during adaptation to new environmental salinity, as suggested by Foskett et al. (1983). Epinephrine is secreted in fish in response to stress, and this hormone may secondarily inhibit ion extrusion at the level of gill chloride cells. Glucagon may also counteract the effect of epinephrine during stress. More studies are needed to clarify the interplay between these antagonistic influences.

This survey on hormonal control of osmoregulation in tilapia suggests several comments.

- All studies presented above were dealing only with one tilapia species Oreochromis mossambicus, which is among the most euryhaline species. The extension of these results to other species should be made with caution, as differences in hormonal control of osmoregulation may account for the diflerences in salinity tolerance observed in tilapia (see reviews Stickney, 1986).

- Most of the experiments described in this chapter were carried out using mammalian hormones: this is an important point for protein hormones, such as PRL, which show significant modifications of their structure during vertebrate evolution (see Clarke and Bern, 1980). Biological effects observed with ovine PRL may not necessarily be observed with tilapia PRL. The recent discovery of two distinct PRL molecules in tilapia (Specker et al., 1985) complicates the problem, confirming the importance of having a complete chemical characterization associated with physiological studies of the different hormones involved in the control of osmoregulation.

\section{CONCLUSION}

Although numerous biological investigations have been undertaken on tilapia osmoregulation and on its endocrine control, our present knowledge is far from allowing us to understand the various aspects of salinity adaptation and particularly factors which control or modulate such adaptation. Most of these physiological studies were carried out on saltwateradapted fish, and few investigations have dealt with changes in osmoregulatory mechanisms during adaptation to low salinity. Several analytical tools have been utilized in recent years, including ion Mux determinations, hormone levels, enzymatic activity measurement and ultrastructural cytological analysis. These techniques should provide a clear picture of the development of adaptative mechanisms, particularly at the level of the gills.

Relatively few species have been studied physiologically to date; investigations have concentrated on species of minor importance for aquaculture, such as $O$. mossambicus. Considering the diversity among tilapia fish, it now secms necessary to extend attention to other tilapia species, particularly those which are of aquacultural significance. The interaction between salinity adaptation and other physiological states, such as reproduction or immunity, needs consideration. Several studies have already reported possible links between salinity adaptation, reproduction (Chevinski and Yashouv, 1971; Watanabe and Kuo, 1985; Fineman-Kalio, 1988) and development of infection (Liao and Chang, 1982). For both fundamental and practical reasons, theses questions deserve more intensive investigation.

\section{REFERENCES}

Al-Amoundi M. M., 1987. The effect of high salt diet on the direct transfer of Oreochromis mossambicus, 0 . spirulus and $O$. aureus/O. miloticus hybrids to sea waters. Aquaculture, 64, 333-338.

Avella M., A. Masoni, M. Bornancin, N. Mayer-Gostan, 1987. Gill morphology and sodium influx in the rainbow trout (Salmo gairdneri) acclimated to artificial freshwater environments. J. Exp. Zool., 241, 159-169.

Assem H., W. Ilanke, 1981. Cortisol and osmotic adjustment of the euryhaline teleost, Sarotherodon mossambicus. Gen. Comp. Endocr., 43. 370-380.

Beamish F. W. H., 1970. Influence of temperature and salinity acclimatation on temperature preferenda of the euryhaline fish Tilapia nilotica. J. Fish Res. Board Can., 27, 1209-1214.

Chervinski J., $\Lambda$. Yashouv, 1981. I'reliminary experiments on the growth of Tilapia aurea in sea water ponds. Bamidgeh, 23, 125-129.

Chervinski J., 1982. Environmental physiology of tilapias. In: The biology and culture of tilapias. R. S. V. Pullin, R. H. Lowe-McConncll Eds., Int. Cent. Liv. Aquat. Resour. Manage, Manilla, 119-128.

Clarke W. C., 1973. Sodium-retaining bioassay of prolactin in the intact teleost Tilapia mossambica acclimated to sea water. Gen. Comp. Endocr., 21, 498-512.

Clarke W. C., H. A. Bern, 1980. Comparative endocrinology of prolactin. In: Hormonal proteins and peptides, C. H. Li, Ed., New York, Academic Ptess, 8, 105-197. 
Dangé A. D., 1986a. Branchial Na ${ }^{+} \cdot \mathrm{K}^{+}$-ATPase inhibition in a freshwater euryhaline teleost, Tilapia (Oreochromis mossambicus) during short-term exposure to toluene or naphthalene: influence of salinity, Entiron. pollut., 42, 273-286.

,- 1986 b. Branchial $\mathrm{Na}^{+}-\mathrm{K}^{+}-\mathrm{ATPase}$ activity in freshwater or saltwater acclimated tilapia Oreochromis (Sarotherodon) mossambicus: cffect of cortisol and thyroxine. Gen. Comp. Endocr., 62, 341-343.

De Renzis G., M. Bornancin, 1984. Ions transport and gill ATPases. In: Fish Physiology, B, W. S. Hoar, D. J. Randall Eds., Acad. Press, 65-104.

Dharmamba M., R. S. Nishioka, 1968. Response of "prolactin secreting" cells of tilapia to environmental salinity. Gen. Comp. Endocr., 10, 409-420.

Dharmamba M., J. Maetz, 1972. Effects of hypophysectomy and prolactin on the sodium balance of Tilapia mossambica in fresh water. Gen. Comp. Endocr., 19, 175183.

Dharmamba M., J. Maetz, 1976. Branchial sodium exchange in scawater adapted Tilapia mossambica: effects of prolactin and hypophysectomy. J. Endocr., 70, 293299.

Dharmamba M., R. I. Handin, J. Nandi, H. A. Bern, 1967. Effect of prolactin on freshwater survival and on plasma osmotic pressure of hypophysectomized Tilapia mossambica. Gen. Comp. Endocr., 6, 295-302.

Dharmamba M., N. Mayer-Gostan, J. Maetz, H. A. Bern, 1973. Effect of prolactin on sodium movement in Tilapia mossambica adapted to seawater. Gen. Comp. Endocr., 21, 179-187.

Dharmamba M., M. Bornancin, J. Maetz, 1975. Environmental salinity and sodium and chloride exchanges accross the gill of Tilapia mossambica. J. Physiol., 70, 627.636.

Doudet T., 1986. Projet pilote de développement de l'aquaculture lagunaire (Côte-d'Ivoire). Rapport annuel, Cent. Tech. Forcst. Trop., Nogent-sur-Marne, France.

Eddy F. B., G. M. O. Maloiy, 1984. Ionic content of body fluids and sodium efllux in Oreochromis alcalicus grahami, a lish living at temperature above $30^{\circ} \mathrm{C}$ and in conditions of extreme alkalinity. Comp. Biochem. Physiol., 78A, 359-361.

Evans D. H., 1980. Kinetic studies of ion transport by fish gill epithelium. Am. J. Physiol., 228, R 224-R 230.

Farghaly A. M., A. A. Ezzat, M. B. Shabana, 1973. Effect of temperature and salinity changes on the blood characteristics of Tilapia zilli G. in Egyptian littoral lakes. Comp. Biochem. Physiol., 46A, 183-193.

Farmer S. W., H. Papkoff, T. A. Bewley, T. Hayashida, R. S. Nishioka, H. A. Bern, C. H. Li, 1977. Isolation and properties of teleost prolactin. Gen. Comp. Endocr., 31, 60-71.

Fineman-Kalio A. S., 1988. Preliminary observations on the effect of salinity on the reproduction and growth of freshwater Nile tilapia, Oreochromis niloticus (L.), cultured in brackish water ponds. Aqua. Fish. Manage., 19, 313-320.

Flick G., J. C. Fenwick, Z. Kolar, N. Mayer-Gostan, S. E. Wendelaar Bonga, 1985. Whole-body calcium Mux rates in cichild teleost fish Oreochromis mossambicus adapted to freshwater. Am. J. Physiol., 249, R 432-R 437.

Foskett J. K., C. Scheffey, 1982. The chloride cell: Definitive identification as the salt-secretory cell in teleosts. Science, 215, 16+1-166.

Foskett J. K., C. D. Logsdon, T. Turner, T. E. Machen, H. A. Bern, 1981. Differentiation of the chloride extrusion mechanism during seawater adaptation of a teleost fish, the cichlid Sarotherodon mossambicus. J. Exp. Biol., 93, 209-224.

Foskett J. K., T. E. Machen, H. A. Bern, 1982a. Chloride secretion and conductance of teleost opercular membrane: effect of prolactin. Am. J. Physiol., 242, R 380R 389.

Foskett J. K., G. M. Hubbard, T. E. Machen, H. A. Bern, $1982 b$. Effects of epinephrine, glucacon and vasoactive intestinal polypeptide on chloride secretion by telcost opercular membrane. J. Comp. Physiol., 146, 27-34.

Foskett J. K., H. A. Bern, T. E. Machen, M. Conner, 1983. Chloride cells and the hormonal control of teleost fish osmoregulation. J. Exp. Biol., 106, 255-281.

Handin R. 1., J. Nandi, H. A. Bern, 1964. Effect of hypophysectomy on survival and on thyroid and interrenal histology of the cichlid teleost Tilapia mossambica, $J$. Exp.-Zool., 157, 339-344.

Hirano T., N. Mayer-Gostan, 1978. Endocrine control of osmoregulation in lish. In: Comparative Endocrinology, P. J. Gaillard, H. H. Boer Eds., Elsevier/North-Holland, Amsterdam, 209-212.

Keys A. B., E. N. Wilmer, 1932. "Chloride secreting cells" in the gill of fishes, with special reference to the common eel. J. Physiol., Lond. 76, 368-378.

Liao I. C., S. L. Chang, 1984. Studies on the feasibility of red tilapia culture in saline water. In: Proc. Int. Symp. Tilapia in Aquaculture, Tel-Aviv Univ., 524-533.

Loretz C. A., 1979. Some effects of ovine prolactin on body fluid composition in the cichlid teleost Sarotherodon mossambicus acclimated to seawater. Gen. Comp. Endocrinol., 38, 38-42.

Maetz J., M. Bornancin, 1975. Biochemical and biophysical aspects of salt excretion by chloride cells in telcosts. Forts. chr. Zool., 22, 322-362.

Mainoya J. R., H. A. Bern, 1982. Effects of tclcost urotensins on intestinal absorption of water and $\mathrm{NaCl}$ in tilapia Sarotherodon mossambicus adapled to fresh water or seawater. Gen. Comp. Endocr., 47, 54-58.

Mainoya J. R., H. A. Bern, 1984. Influence of vasoactive intestinal peptide and urotensin II on the absorption of water and $\mathrm{NaCl}$ by the anterior intestine of the tilapia. Sarotherodon mossambicus. Zinol. Sci., 1, 100-105.

Morissens P., 1987. Projet de développement de la pisciculture. Rapport Annuel, Cent. Tech. For. Trop., Nogentsur-Marne, France.

Nicoll C. S., W. S. Wilson, R. S. Nishioka and H. A. Bern, 1981. Blood and pituitary prolactin levels in tilapia (Sarotherodon mossambicus, Teleostei) from different salinities as measured by a homologous radio-immunoassay. Gen. Comp. Endocr., 44, 365-373.

Payan P., J. P. Girard, N. Mayer-Gostan, 1984. Branchial ion movements in telcosts: the roles of respiratory and 
chloride cells. In: Fïsh Physiology, XB. W. S. Hoar, D. J. Randall Eds., Academic Press, New York, 39-63.

Payne A. I., 1984. Estuarine and salt tolerant tilapias. In: Proc. Int. Symp. Tilapia in aquaculture. Tel Aviv Univ., 534-543.

Philippart J. C., J. C. Ruwet, 1982. Ecology and distribution of tilapias. The biology and culture of tilapias, R. S. V. Pullin, R. H. Lowe-McConnell Eds., Int. Cent. Living Aquat. Resour., Manage, Manilla, 15-59.

Potts W. T. W., M. A. Foster, P. P. Rady, G. P. Howell, 1967. Sodium and water balance in the cichlid teleost Tilapia mossambica. J. Exp. Biol., 47, 461-470.

Specker J. L., D. S. King, R. S. Nishioka, K. Shirahata, K. Yamaguchi, H. A. Bern, 1985. Isolation and partial characterization of a pair of prolactins relcased in vitro by the pituitary of a cichlid fish, Oreochromis mossambicus. Proc. Nall. Acad. Sci. U.S.A., 82, 7490-7494.

Stickney R. R., 1986. Tilapia tolcrance of saline waters: a review. Prog. Fish Cult., 48, 161-167.

Valverde Y. R., O. F. Arbex, M. V. C. Fabria, 1982. Adaptive response of $\left(\mathrm{Na}^{+}, \mathrm{K}^{+}\right)$ATPase from gills and intestine of Plecostomus ancistroides and Tilapia rendalli to a gradual increase in water salinity. Rev. Bras. Biol., 42, 129-134.
Watanabe W. O., C. M. Kuo, 1985. Observations on the reproductive performance of Nile tilapia (Oreochromis niloticus) in laboratory aquaria at various salinitics. Aquaculture, 49, 315-323.

Watanabe W. O., C. M. Kuo, M. C. Huang, $1985 a$. The ontogeny of salinity tolerance in the tilapias Oreochromis aureus, 0 . niloticus and an 0 . mossambicus $\times 0$. niloticus hybrid, spawned and reared in freshwater. Aquaculture, 47, 353-367.

Watanabe W. O., C. M. Kuo, M. C. Huang, 1985b. Salinity tolerance of Nilc tilapia fry (Oreochromis niloticus) spawned and hatched at various salinities. Aquaculture, 48, 159-176.

Wendelaar Bonga S. E., J. C. Van der Meij, 1981. Effect of ambient osmolarity and calcium on prolactin cell activity and osmotic water permeability on the gills in the teleost Sarotherodon mossambicus. Gen. Comp. Endocr., 43, 432-442.

Wendelaar Bonga S. E., R. K. Pang, P. K. T. Pang, 1986. Hypocalcemic eflects of bovine parathyroid hormone (134) and stannius corpuscle homogenates in teleost fish adapted to low calcium water. J. Exp. Zool., 240, 363367.

Whitfield A. K., S. J. M. Blaber, 1976. The effect of temperature and salinity on Tilapia rendalli, Boulenger, 1896. J. Fish Biol., 9, 99-104. 